\title{
Huzurevinde Kalmakta Olan Yaşılırda Yaşı İstismarının Bir Türü Olarak Ekonomik İstismar
}

\author{
Financial Abuse as a Type of Elderly Abuse among Elderly People Residing in \\ Senior Centers
}

\section{Taner ARTANa}

\begin{abstract}
Özet Giriş ve Amaç: Bütün dünyada, yaşlı istismarından etkilenen yaşlıların sayısı giderek artmaktadır. Özellikle ülkemizde "ekonomik açıdan istismar edilen yaşlılar üzerine" yapılmış araştırmalar sınırlı sayıdadır. Bu araştırmanın amacı; huzurevine girmeden önce ve girdikten sonraki süreçte yaşlıların aile üyeleri tarafindan ekonomik istismara maruz bırakılıp bırakılmadıklarının tespitidir. Gereç ve yöntem: İstanbul'da Aile ve Sosyal Politikalar Bakanlığı'na bağlı dört huzurevinde kalmakta olan 100 yaşlı ile araştırmacı tarafindan geliştirilen konomik Yaşlı İstismarını Belirleme Formu ile veriler yüz yüze görüşme tekniği ile toplanmıştır. Bulgular: Yaşlıların huzurevine girmeden önceki dönemde daha fazla ekonomik istismara uğradıkları, huzurevine girdikten sonraki süreçte ise ekonomik istismar oranın azalmakla birlikte varlığını önemli ölçüde sürdürdüğü tespit edilmiştir. Sonuç: Yaşlıların önemli ölçüde "ekonomik istismara" maruz kaldıkları belirlenmiş̧ir.
\end{abstract}

Anahtar Kelimeler: Aile içi şiddet, ekonomik istismar, yaşlılık, yaşlı istismarı.

\begin{abstract}
Intrduction and Goal: The number of elderly people affected by elderly abuse is increasing day by day in all over the World. Studies done on financial abuse of elderly people are very limited especially in Turkey. The goal of this research is to define whether elderly people had been exposed to financial abuse before or/and after being placed in senior centers. Method: 100 elderly people living in Etiler Nursing and Rehabilitation Center for Elderly People, Zeytinburnu Semiha Şakir Senior Center and Sultangazi Senior Center had been interviewed face to face. Findings: It was determined through the research that most of the elderly people had been exposed to financial abuse to a considerable extent. It has seen that most of the participants had gone through financial abuse more, before being replaced to senior centers. Yet, most stated that even though the density of financial abuse was decreased after being replaced to senior centers, they keep experiencing it to some extent. Results: It was found out that elderly people had been exposed to "economic abuse" considerably.
\end{abstract}

Key words: Domestic violence, economic abuse, senility elderly abuse.

\section{GíRİs}

Sosyal bir sorun olarak dünya genelinde giderek artan yaşlı istismarı önemli bir problemdir.

Modernleşme, sanayileşme, yaşlı nüfus oranın artması, kadınların daha fazla çalışma hayatına girmesi yaşlı istismarı oranını artırmaktadır. Dünya genelinde yaşlı istismarının görülme sıklığ $\% 1$ ile $\% 35$ arasında değişen oranlara sahiptir. Yaşlı istismarı oranlarının değişkenliği araştırma türü ve modeline göre farklılık göstermesinden kaynaklanmaktadır. Kimi araştırmacılara göre ise bu oranlar buzdağının görünen kısmı olup aslında yaşlı istismarının görünenin çok daha üzerinde oranlara sahip olduğu öngörülmektedir. ${ }^{1}$

Yaşlı istismarına ilişkin yasal bildirimde bulunma zorunluluğu 1976 yılında, Kanada, İsrail ve ABD'de 43 eyalette başlamıştır. ${ }^{2}$

Geliş Tarihi/Received: 25-12-2015 / Kabul Tarihi/Accepted: 26-01-2016

${ }^{a}$ Yard. Doç. Dr. İstanbul Üniversitesi Sağlık Bilimleri Fakültesi Sosyal Hizmet Bölümü, e-mail: taner.artan@istanbul.edu.tr

Sorumlu Yazar Adres/ Correspondence: Yard. Doç. Dr. Taner ARTAN, İstanbul Üniversitesi Sağlık

Bilimleri Fakültesi Sosyal Hizmet Bölümü, taner.artan@istanbul.edu.tr

Atıf: Artan T. Huzurevinde Kalmakta Olan Yaşlılarda Yaşlı İstismarının Bir Türü Olarak Ekonomik İstismar. HSP 2016;3(1):48-56.

To cite this article: Artan T. Financial Abuse as a Type of Elderly Abuse among Elderly People Residing in Senior Centers HSP 2016;3(1):48-56. 
Benzer düzenlemelerin özellikle 1980 ve 2000'li yıllar arasında dünyanın birçok gelişmiş ve gelişmekte olan ülkesinde yaşlı istismarını engellemek amacı ile yapıldığ 1 bilinmektedir. ${ }^{2}$ Yaşlı istismarı dünya genelinde hızlı bir gelişme göstermiş olup, 1997 yılında altı kıtanın temsili ile "Yaşlı İstismarını Önleme Uluslararası Ağı" (INPEA) kurulmuştur. ${ }^{2}$ Ülkemizde ise henüz doğrudan yaşlı istismar ve ihmalini önlemeye yönelik bir düzenleme yapılmamış olup, yalnızca Aile ve Sosyal Politikalar Bakanlığına bağlı Alo 183 hattı ile konuya ilişkin ihbarlar değerlendirilmektedir.

Yaşlı istismarı alanındaki çalışmalar 1970'lerde eş ve çocuk istismarı alanında yapılan "aile içi şiddet" araştırmaları sonucunda, ortaya çıkmaya başlamıştır. Yaşlı istismarı Aile içi şiddetin bir türü olarak, literatürde ilk kez 1975 yilında Baker ve Burston tarafindan "granny battering" olarak tanımlanmıștır. Dünya Sağlık Örgütü ${ }^{6}$ ve yaşlı istismarının önlenmesi uluslararası ağı tarafindan "yaşlı istismarı": "yaşlı insanlara karşı herhangi bir güven ilişkisi içerisinde sıkıntı ve zarara neden olabilecek bir kez veya tekrarlanan hareket veya uygun davranış eksikliğì" olarak tanımlanmaktadır.

Yaşlı istismarı konusunda sosyal ve kültürel farklılıklardan dolayı tam bir fikir birliği bulunmamakla birlikte kavramsal olarak üç kategoride ele alınmaktadır. Bunlar; aile içi istismar, kurumsal istismar ve kendi kendini istismardır. Diğer taraftan yaşlılara yönelik istismarın birçok farklı türü söz konusudur. Bunlar; psikolojik, fiziksel, cinsel ve ekonomik olarak sınıflandırılmaktadır. ${ }^{7} \quad$ Yaşlıların istismara maruz kalma riskini artıran faktörler arasında; bilișsel bozukluk, fonksiyonel yetersizlik, sosyal izolasyon, yaş, irk, gelir durumu, aile geçmişi, yaşam olayları, demans ve depresyon sayilabilir. ${ }^{8}$

Her ne kadar istismara uğrayan yaşlılara ilişkin veriler sınırlı olsa da eldeki verilere göre, orta ve üst gelir düzeyine sahip ülkelerde yaşl1ların maruz kaldıkları istismar türleri ve görülme sıklığına baktığımızda, fiziksel istismar \%0,2 ile 4,9 , cinsel istismar $\% 0.04$ ile 0.82 , psikolojik istismar \%0,7 ile 6,3, ekonomik istismar \%1 ile 9,2 ve ihmalin \%0,2 ile 5,5 arasında değisştiği görülmektedir. ${ }^{6} \mathrm{Bu}$ verilerden anlaşıldı ğ 1 gibi yaşlilar en fazla ekonomik istismara maruz kalmaktadırlar. ${ }^{2}$ Yapılan birçok araştırmada da yaşlılara yönelik en yaygın istismar türünün ekonomik istismar olduğu tespit edilmiştir. ${ }^{10}$
Ekonomik yaşlı istismarı yaşlıya ait "fon veya kaynakların yasadışı veya uygunsuz sömürü ve/veya kullanımı" olarak tanımlanmaktadır. ${ }^{9}$

Ekonomik yaşlı istismarının belirtileri arasında; yaşlı kişinin düzensiz olarak bankadan para çekmesi, yaşlının mal varlığında nedensiz azalma görülmesi, yaşlı kişiye ait kıymetli takıların veya kişisel eşyalarının kaybı, kredi kartı hesaplarında şüpheli harcamalar, nedensiz olarak harcamalarını karşılayamama durumuyla baș başa kalma, tedavi edilemeyen tıbbi ya da ruhsal hastalığın varlığı ve yaşlının bakım seviyesinin geliri veya varliklarıyla orantılı olmamas1 sayılabilir. ${ }^{-11-13}$

Gününmüz dünyasında yaşlı istismarının giderek görünür hale gelmesine etki eden en önemli etken dünya nüfusunun giderek yaşlanmasıdır. 2015 yılında dünya nüfusunun $\% 12$ 'si 60 yaş veya üzeri 901.000 .000 kişiden oluşmaktadır. 60 yaş üzeri nüfus yılda $\% 3.26$ oranında artış göstermektedir. Şu anda, Avrupa 60 yaş ve üstü nüfus $\% 24$ oranındadır. Ancak, 2050 yılında, Afrika'nın dışında dünyanın tüm önemli bölgelerinde çok hızlı bir yaşlanma sürecinin olacağ 1 öngörülmektedir. Dünyada yaşlı kişilerin sayısının 2030 yılında 1,4 milyara ve 2050 yılında 2,1 milyara ulaşacağ 1 tahmin edilmektedir. ${ }^{14-15}$ Dünya Sağl1k Örgütünün (WHO) 2015 verilerine göre ise, her 10 yaşlıdan birisi istismara maruz kalmaktadır. ${ }^{6}$

Benzer bir durum, Türkiye açısındanda söz konusu olup; 2015 y1lı itibariyle, 60 yaş ve üzeri grupta yer alan yaşlı sayısı \%11.2 dir. 2050 yılına kadar, \%26.6'ya yükseleceği yükseleceği tahmin edilmektedir. ${ }^{15} \mathrm{Bu}$ verilerden anlaşılacağ1 üzere, ülkemizde de yaşlı istismarının, yaşlı nüfus oranındaki artışa paralel önümüzdeki süreçte çocuk ve eş istismarı kadar belirgin hale geleceği söylenebilir. ${ }^{16}$

$\mathrm{Bu}$ araştırma huzurevinde kalmakta olan 60 yaş üzeri akıl ve ruh sağlığ 1 yerinde olan yaşlılardan herhangi bir gelire (emekli maaşı, kira geliri, banka geliri vb.) sahip olanların huzurevine girmeden önce ve girdikten sonraki süreçte çocukları ya da diğer yakınları tarafından ekonomik istismara maruz birakılıp bırakılmadıklarını belirlemek amaciyla yapılmıştır. Özellikle bu çalışmada yaşlı istismarının önemli bir boyutunu teşkil eden ekonomik istismarın tespiti ve gerekçelerinin ele alınarak değerlendirilmesi amaçlanmıştır. 


\section{YÖNTEM}

Araştırmanın evreni, İstanbul'da Aile ve Sosyal Politikalar Bakanlığı'na bağlı Bahçelievler Huzurevi Yaşılı Bakım ve Rehabilitasyon Merkezi, Zeytinburnu Semiha Şakir Huzurevi Müdürlüğü, Etiler Huzurevi Yaşlı Bakım ve Rehabilitasyon Merkezi ve Sultangazi Huzurevi Müdürlüklerinde kalmakta olan, akıl ve ruh sağlığ yerinde olan ve son bir yıldır huzurevinde kalan yaşlilardan oluşturulmuştur. Örneklem grubu kriterlerine uyan ve görüşmeyi kabul eden 100 yaşlı araştırmanın evrenini oluşturmuştur.

Araştırmada belirlenen amaçlar doğrultusunda, betimsel tarama modeli kullanılmıştır. Araştırma verileri, yukarıda adı geçen huzurevlerinde son bir yıldır kalmakta olan yaşlılara araştırmacı tarafından geliştirilen "Ekonomik Yaşlı İstismarını Belirleme Formu" uygulanarak toplanmıştır. Yaşlılara görüşme formları, 15 Ekim - 30 Kasım 2015 tarihleri arasında her bir huzurevinde 25 yaşliyla "yüz yüze" yapılan görüşmelerle uygulanmıştır.

Ekonomik yaşlı istismarını belirleme formunda, yaşlının demografik verilerinin yanı sıra çocukları ve akrabaları ile ilişkileri ve kendilerine yönelik uygulanabilecek istismara ilişkin, özellikle ekonomik istismara ilişkin ayrıntılı sorular yer almaktadır. "Ekonomik Yaşlı İstismarını Belirleme Formu" 37 soruyu içermektedir.

Araştırmada elde edilen veriler SPSS 23 İstatistik programı kullanılarak değerlendirilmiştir.

\section{BULGULAR}

Araştırma sonucunda elde edilen bulgular; Araştırma kapsamına giren yaşlıları tanıtıcı bulgular, Yaşlıların çocukları ile ilişkilerini betimleyici bulgular, Yaşliların sosyal ilişsilerini betimleyici bulgular, Yaşlıların ekonomik istismara uğrama durumlarına ilişkin bulgular ve Yaşliların huzurevine gelmelerine neden olan bulgular olmak üzere beş ana grupta ele alınmıştır.

Araştırma sonucu ortaya çıkan bulgulara ilișkin olarak tablolar hazırlanmıș ve her bir tabloya ilişkin yorumlara aşağıda yer verilmiştir.

Yaşlıların demografik bulguları Tablo 1'de yer almaktadır. Tablo 1'e göre, katılımciların $\% 50$ 'si erkelerden \%50'si kadınlardan oluşmaktadır. Araştırmaya katılan yaşlıların yaş ortalamas1 ise 74,4 olup, standart sapmas1 2.23'tür. Yaşlıların medeni durumlarına baktığımızda, ilk sırada dul olanların (\%57) yer aldığ 1 , bunu boşanmış olanların (\%18) takip ettiği, üçüncü sırada evli olanların (\%14), dördüncü sırada ise hiç evlenmemişlerin (\%11) yer aldığı görülmektedir. Yaşlıların eğitim

Tablo 1. Sosyo-Demografik özellikler (N=100)

\begin{tabular}{|c|c|c|}
\hline \multicolumn{3}{|c|}{ Yaş Ortalaması Ort $\pm \mathbf{S S} 74,4 \pm 2.23$} \\
\hline Değişkenler & $\mathrm{N}$ & $\%$ \\
\hline $\begin{array}{l}\text { Cinsiyet } \\
\text { Erkek } \\
\text { Kadın }\end{array}$ & $\begin{array}{l}50 \\
50\end{array}$ & $\begin{array}{l}(50) \\
(50)\end{array}$ \\
\hline $\begin{array}{l}\text { Medeni Durum } \\
\text { Evli } \\
\text { Bekar } \\
\text { Dul } \\
\text { Boşanmış } \\
\end{array}$ & $\begin{array}{l}14 \\
11 \\
57 \\
18\end{array}$ & $\begin{array}{l}(14) \\
(11) \\
(57) \\
(18) \\
\end{array}$ \\
\hline $\begin{array}{l}\text { Eğitim Durumu } \\
\text { Okuryazar değil } \\
\text { Okuryazar değil } \\
\text { İlkokul } \\
\text { Ortaokul } \\
\text { Lise } \\
\text { Üniversite } \\
\end{array}$ & $\begin{array}{c}11 \\
6 \\
41 \\
17 \\
19 \\
6 \\
\end{array}$ & $\begin{array}{l}(11) \\
(6) \\
(41) \\
(17) \\
(19) \\
(6)\end{array}$ \\
\hline $\begin{array}{l}\text { Aylık Gelir Durumu } \\
\text { (2022 Yaşlılık Maaşı } \\
\text { Dahil) } \\
\text { Evet } \\
\text { Hayır } \\
\end{array}$ & 100 & $\begin{array}{c}(100) \\
(0)\end{array}$ \\
\hline $\begin{array}{l}\text { Aylık Gelir (TL) } \\
\text { Bilmiyor (Çocukları alıyor) } \\
150-1000 \\
1001-1500 \\
1501-2000 \\
2001-2500 \\
2501-+\end{array}$ & $\begin{array}{c}5 \\
33 \\
47 \\
9 \\
2 \\
4\end{array}$ & $\begin{array}{l}(5) \\
(33) \\
(47) \\
(9) \\
(2) \\
(4)\end{array}$ \\
\hline $\begin{array}{l}\text { Aylık Gelirini Yeterli } \\
\text { Bulma Durumu } \\
\text { Yeterli } \\
\text { Ancak Yetiyor } \\
\text { Yetersiz } \\
\end{array}$ & $\begin{array}{l}14 \\
47 \\
39\end{array}$ & $\begin{array}{l}(14) \\
(47) \\
(39)\end{array}$ \\
\hline $\begin{array}{l}\text { Halen Bir İşte Çalışma } \\
\text { Durumu } \\
\text { Evet } \\
\text { Hayır }\end{array}$ & $\begin{array}{c}1 \\
99\end{array}$ & $\begin{array}{l}(1) \\
(99)\end{array}$ \\
\hline
\end{tabular}

durumlarına bakıldığında ilk sırada (\%41) ilkokul mezunları, ikinci sırada lise üçüncü sırada (\%17) ortaokul mezunları, dördüncü sirada okuryazar olmayanlar $(\% 11)$, son sirada ise üniversite mezunları (\%6) ve okuryazar olanlar (\%6) bulunmaktadır. Yaşlıların \% 
100'ünün herhangi bir kaynaktan gelire sahip olduğu anlaşılmaktadır. Yaşlıların gelir durumlarına bakıldığında, birinci sirada 10011500 TL aylık gelire sahip olanların (\%47) yer aldığ1, bunu ikinci sırada 150-1000 TL grubunda bulunanların (\%33) takip ettiği, 15012000 TL grubunda yer alanların (\%9) ise üçüncü sırada takip ettiği, dördüncü sırada ise gelirini bilmeyen (çocukları tarafından maaşı alınan) yaşlıların (\%5) takip ettiği, beşinci sırada $2501+$ grubunda yer alanların (\%4) takip ettiği ve son sirada 2001 - 2500 TL grubunda yer alan (\%2) yaşlıların takip ettiği tespit edilmiştir. Yaşlıların aylık gelirlerini yeterli bulup bulmadıklarına baktığımızda, ilk sırada ancak yetiğini (\%47) ifade edenlerin bulunduğu, bunu ikinci sirada gelirlerini yetersiz bulanların (\%39) takip ettiği ve son sirada ise yeterli bulanların (\%14) takip ettiği görülmektedir. Ayrıca katılımcı yaşlilardan sadece birisinin aktif çalışma yaşamına devam ettiği görülmüştür.

Tablo 2'ye göre, yaşl1ların \%82'sinin çocuk sahibi olduğu, buna karşıllk \%18'nin çocuk sahibi olmadığı görülmektedir. Çocuk sahibi olan yaşlıların ortalama çocuk sayıları 3'tür. Yaşlıların çocuk sayılarının oransal dağılımına bakıldığında, ilk sırada iki çocuklu olanların (\%31.70), ikinci sırada üç çocuklu olanların (\%29.27), üçüncü sırada bir çocuklu olanların (\%18.29), dördüncü sırada dört çocuklu olanların (\%9.76), beşinci sırada beş ve altı çocuk sahibi olanların $(\% 4.88)$ ve son sırada dokuz çocuklu (\%1.22) olanların geldiği görülmektedir. Yaşlıların $(n=82)$ çocukları ile görüşme sıklığına baktığımızda; ilk sırada çocukları ile s1k görüşenlerin $(\% 40.24)$ yer aldığı, bunu ikinci sırada nadir olarak görüşenlerin (\%37.81) takip ettiği ve son sirada ise hiç görüşmeyenlerin (\%21.95) yer aldığ1 belirlenmiştir. Ayrıca anne ya da babasının ekonomik durumlarıyla ilgilenmeyen çocukların oranın $(\% 71.95)$, ilgilenenlere $(\% 28.05)$ oranla oldukça yüksek olduğu görülmüştür.

Tablo 3'de görüldüğü üzere yaşlıların yarıdan fazlasının (\%56) huzurevine girmeden önce yalnız yaşadıkları, bunu ikinci sırada (\%21) eşinin yanında yaşayanların takip ettiği, üçüncü sırada $(\% 9)$ ise geçici olarak komșu, arkadaş vb. yanında kalanlar) diğer seçeneğinde yer alanlar ile yaşayanlar, dördüncü sırada (\%8) kızı ile yaşayanlar, beşinci sırada (\%5) oğlu yanında yaşayanlar, son sırada ise akraba yanında yaşayanlar (\%1) olduğu tespit edilmiştir.

Tablo 2. Yaşlıların Çocukları İle İlişkilerini Betimleyici Bulgular

\begin{tabular}{|c|c|c|}
\hline & $\mathbf{N}$ & $\%$ \\
\hline \multicolumn{3}{|l|}{ Çocuk Durumu } \\
\hline Evet & 82 & $(82)$ \\
\hline Hayır & 18 & (18) \\
\hline \multicolumn{3}{|l|}{ Çocuk Sayısı* } \\
\hline Bir & 15 & $(18,29)$ \\
\hline İki & 26 & (31.70) \\
\hline Üç & 24 & (29.27) \\
\hline Dört & 8 & $(9.76)$ \\
\hline Beş & 4 & $(4.88)$ \\
\hline Alt & 4 & $(4.88)$ \\
\hline Dokuz & 1 & $(1.22)$ \\
\hline \multicolumn{3}{|l|}{ Çocukları İle } \\
\hline Görüşsme Sıklığı & & \\
\hline S1k Görüşen & 35 & $\begin{array}{l}(40.24) \\
(37.81)\end{array}$ \\
\hline Nadir Görüşen & & (J1.01) \\
\hline Görüşmeyen & 18 & (21.95) \\
\hline \multicolumn{3}{|l|}{ Cocuklarının } \\
\hline \multicolumn{3}{|l|}{ Ekonomik } \\
\hline \multicolumn{3}{|l|}{ Durumlarıyla } \\
\hline \multicolumn{3}{|l|}{ İlgilenme } \\
\hline Durumu & 23 & $(28.05)$ \\
\hline $\begin{array}{l}\text { Yeterli } \\
\text { Yeteriz }\end{array}$ & 59 & (71.95) \\
\hline
\end{tabular}

* $\mathrm{N}=82$

Yaşlıların önemli bir kısmı (\%44) ailelerindeki hiç kimsenin kendilerini istemedikleri yönünde bir düşünceye sahip olduklarını ifade etmektedir. Aile içi ihmal ve istismarla yakından ilişkili olan alkol ya da uyuşturucu kullanımına ilişkin olarak sorulan soruya yaşlıların yarıdan fazlası (\%81) hayır cevabı verirken aşırı alkol kullanımı olduğunu ifade edenlerin oranı ise (\%19) yaklaşık $1 / 5$ orandadır. Aşırı miktarda alkol kullanan yaşlı ve yaşlı yakınlarının oransal dağılımına baktığımızda ilk sırada (\%8) çocukların geldiği, bunu ikinci sırada damatların (\%5) takip ettiği ve son sırada kendilerinin (\%3) ve eşlerinin (\%3) yer aldığı anlaşılmaktadır. Ayrıca yaşlılara ailelerinde güven duymadıkları kişilerin olup olmadığı sorulmuştur. Yaşlıların yarıdan fazlası $(\% 67)$ güven sorunu yaşamazken $(\% 33)$ önemli bir kısmı ise aile içinde güven sorunu yaşadıklarını ifade etmiştir. 
Tablo 3. Yaşlıların Sosyal İlişkilerini Betimleyici Bulgular ( $N=100)$

n

Huzurevine Gelmeden
Önce Birlikte Yaşadığı
Kişi/Kişiler
Yalnız
Eşi
Oğlu
Kızı
Akraba
Diğer (komşu, bakıcı vb.)

\begin{tabular}{lcc}
\hline $\begin{array}{l}\text { Ailelerince } \\
\text { İstenmediklerini Düşünen } \\
\text { Yaşlıların Dağılımı } \\
\text { Evet }\end{array}$ & \\
Hayır & 44 & $(44)$ \\
\hline Ailede Aşırı Miktarda & 56 & $(56)$ \\
Alkol Kullanan Yaşlı ve & & \\
Yakınlarının Dağılımı & & \\
Kendisi & 3 & $(3)$ \\
Eşi & 3 & $(3)$ \\
Damadı & 5 & $(5)$ \\
Çocukları & 8 & $(8)$ \\
Kullanmayan & 81 & $(81)$ \\
\hline Yaşlıların (Ailede) & & \\
Güvenmediği Kişilerin & & \\
Dağlımı & & \\
Hiç kimseye güvenmiyor & 15 & $(15)$ \\
Çocukları & 9 & $(9)$ \\
Damat & 5 & $(5)$ \\
Gelin & 3 & $(3)$ \\
Kardeş & 1 & $(1)$ \\
Güven sorunu olmayan & 67 & $(67)$ \\
\hline
\end{tabular}

Güven sorunu yaşayan yaşlıların oransal dağılımına bakıldığında, ilk sırada hiç kimseye güven duymayanların $(\% 15)$ yer aldığı, bunu ikinci sırada çocuklarına güven duymayanların (\%9) takip ettiği, üçüncü sırada damatlarına güven duymayanların (\%5) takip ettiği, dördüncü sirada gelinlerine güven duymayanların (\%3) yer aldığ 1 ve son sirada kardeşine güven duymayanların (\%1) yer aldığ 1 tespit edilmiştir.

Tablo 4'de görüldüğü üzere, yakınları tarafından herhangi bir şekilde ekonomik istismara maruz kalanların oldukça yüksek bir orana (\%33) sahip olduğu görülmektedir. Yaşlılara yönelik ekonomik istismarda bulunanların kim ya da kimlerden oluştuğuna baktığımızda; istismarda bulunanların bir veya birden fazla oldukları görülmüş olup ilk sırada çocuklarının (\%44) yer aldığı, bunu ikinci sırada damatların (\%12) takip ettiği, üçüncü sırada yeğenlerin (\%11), dördüncü sırada kardeş, torun ve arkadaşlarının (\%9) bulunduğu ve son sırada ise eşlerinin (\%7) olduğu görülmektedir.

Yaşlilardan maddi yarar sağlamaya çalışanların hangi gerekçeye dayalı olarak bunu yaptıklarına baktığımızda; maddi sıkıntıyı gerekçe gösterenlerin (\%60) ilk sırada yer aldığı, mal almak için (ev, araba vb.) istismarda bulunanların (\%26) ikinci sırada bulunduğu, bunu üçüncü sırada iș kurmak gerekçesi ile (\%11) istismarda bulunanların takip ettiği ve son sırada eğitim için para isteyenlerin (\%4) bulunduğu görülmektedir.

Huzurevine girdikten sonra yakınları tarafindan ekonomik istismara maruz bırakılan yaşlıların dağılımına bakıldığında, huzurevi öncesi döneme göre ekonomik istismara maruz kalma oranlarında (\%33) azalma görülmesine rağmen, yine de ekonomik istismara uğrayan yaşlı sayısının azımsanamayacak bir oranda (\%14) olduğu görülmektedir.

Huzurevinde kalmakta iken ekonomik istimara maruz kalan yaşl1lardan yararlanmaya çalışanların dağılımına baktığımızda; (bu ve aşağıdaki diğer soruda istismarda bulunanların bir veya birden fazla olmasindan dolayı $\mathrm{n}=14$, $\mathrm{n}=44$ olarak gözükmektedir). İlk sırada (\%55) çocuklarının yer aldığ 1 görülmektedir. Bunu ikinci sırada (\%9) damatları, üçüncü sırada ise kardeşleri, torunları, yeğenleri ve arkadaşlarının (\%7) geldiği, son sırada ise eş ve gelinlerin (\%5) geldiği görülmektedir.

Maddi isteklerinin karşılanmasını isteyen yaşlı yakınlarının yaşlılara karşı ne tür tepkilerde bulunduklarının dağılımına bakıldığında, ilk sırayı (\%64) konuşmamak ve gelip ziyaret etmeyerek cezalandirma yolunu seçen yaşlı yakınları alırken, son sırada (\%36) ise kızmak, bağırmak ve aşağılamak yolunu tercih eden yaşlı yakınları yer almaktadır. 
Tablo 4. Yaşlıların Ekonomik İstismara Uğruma Durumlarına İlişkin Bulgular

\begin{tabular}{|c|c|c|}
\hline & $\mathbf{n}$ & $(\%)$ \\
\hline $\begin{array}{l}\text { Huzurevine Girmeden Önce } \\
\text { Ekonomik İstismara Maruz } \\
\text { Kalan Yaşlıların Dağılımı } \\
(\mathbf{N}=100) \\
\text { Evet } \\
\text { Hayır }\end{array}$ & $\begin{array}{l}33 \\
67\end{array}$ & $\begin{array}{l}(33) \\
(67)\end{array}$ \\
\hline $\begin{array}{l}\text { Yaşlıdan Ekonomik olarak } \\
\text { Yararlanmayı Çalışanların } \\
\text { Dağılımı }(\mathbf{n}=\mathbf{3 3}) \\
\text { Eşi } \\
\text { Kardeşi } \\
\text { Çocukları } \\
\text { Damat } \\
\text { Torun } \\
\text { Yeğen } \\
\text { Arkadaş }\end{array}$ & $\begin{array}{c}4 \\
5 \\
25 \\
7 \\
5 \\
6 \\
5\end{array}$ & $\begin{array}{l}(7.01) \\
(8.77) \\
(43.85) \\
(12.27) \\
(8.77) \\
(10.56) \\
(8.77) \\
\end{array}$ \\
\hline $\begin{array}{l}\text { Yaşlılardan Maddi Yarar } \\
\text { Sağlama Gerekçelerinin } \\
\text { Genel } \\
\text { Dağılımı (n=33) } \\
\text { Maddi Sıkıntı } \\
\text { Mal almak (ev, araba vb.) } \\
\text { İş kurmak için } \\
\text { Eğitim } \\
\end{array}$ & $\begin{array}{c}34 \\
15 \\
6 \\
2 \\
\end{array}$ & $\begin{array}{c}(59.65) \\
(26.32) \\
(10.52) \\
(3.51)\end{array}$ \\
\hline $\begin{array}{l}\text { Huzurevine Girdikten Sonra } \\
\text { Yakınları Tarafından } \\
\text { Ekonomik İstismara Maruz } \\
\text { Bırakılan Yaşlıların Dağılımı } \\
(\mathbf{n}=\mathbf{1 0 0}) \\
\text { Evet } \\
\text { Hayır }\end{array}$ & $\begin{array}{l}14 \\
86\end{array}$ & $\begin{array}{l}(14) \\
(86)\end{array}$ \\
\hline $\begin{array}{l}\text { Huzurevinde Kalmakta İken } \\
\text { Ekonomik İstismara Maruz } \\
\text { Kalan Yaşlılardan } \\
\text { Yararlanmaya Çalışanların } \\
\text { Dağlımı (n=14) } \\
\text { Eşi } \\
\text { Kardeşi } \\
\text { Çocukları } \\
\text { Damat } \\
\text { Torun } \\
\text { Gelin } \\
\text { Yeğen } \\
\text { Arkadaş }\end{array}$ & $\begin{array}{c}2 \\
3 \\
24 \\
4 \\
3 \\
2 \\
3 \\
3\end{array}$ & $\begin{array}{c}(4.54) \\
(6.82) \\
(54.55) \\
(9.09) \\
(6.82) \\
(4.54) \\
(6.82) \\
(6.82\end{array}$ \\
\hline
\end{tabular}

Tablo 4'ün devamı

\begin{tabular}{|c|c|c|}
\hline $\begin{array}{l}\text { Maddi İsteklerinin } \\
\text { Karşılanmasını İsteyen } \\
\text { Yaşlıların Yakınlarının } \\
\text { Yaşılıara Karşı Ne Tür } \\
\text { Tepkilerde Bulunduklarının } \\
\text { Dağlımı(n=14) } \\
\text { Kızmak, bağırmak, aşağılamak } \\
\text { Konuşmamak, gelip ziyaret } \\
\text { etmemek }\end{array}$ & $\begin{array}{l}16 \\
28\end{array}$ & $\begin{array}{l}(36.36) \\
(63.64)\end{array}$ \\
\hline $\begin{array}{l}\text { Huzurevinde Kalmakta İken } \\
\text { Yakınları İçin Kredi Çekmek } \\
\text { ve Ödemek Zorunda } \\
\text { Bırakılan Yaşlıların Dağılımı } \\
(\mathbf{n}=\mathbf{1 0 0}) \\
\text { Evet } \\
\text { Hayır }\end{array}$ & $\begin{array}{c}7 \\
93\end{array}$ & $\begin{array}{r}(7) \\
(93)\end{array}$ \\
\hline
\end{tabular}

Huzurevinde kalmakta iken yakınları için kredi çekmek ve ödemek zorunda birakılan yaşlıların dağılımına bakıldığında, yaşlıların (\% 7) azımsanmayacak bir oranın bu durumla karşı karşıya kaldığı görülmektedir.

Tablo 5. Yaşlıların Huzurevine Gelme Nedenleri $(\mathrm{N}=100)$

\begin{tabular}{|l|c|c|}
\hline & n & (\%) \\
\hline & 49 & $(49)$ \\
Yalnızlık & 24 & $(24)$ \\
Rahat etmek için & 3 & $(3)$ \\
Gelin istemediği için & 5 & $(5)$ \\
Ailevi sorunlar & 5 & $(5)$ \\
Kalacak yeri olmadığı için & & \\
Ekonomik nedenler & 10 & $(10)$ \\
Çocuklar istemediği için & 4 & $(4)$ \\
\hline
\end{tabular}

Tablo 5'de görüldüğü üzere yaşlıların huzurevine girme nedenleri yer almaktadir. Yaşlıların huzurevine girme nedenlerine baktığımızda en önemli nedenin yalnızlık olduğu (\%49) görülmektedir. Bunu ikinci sırada ev ortamında yaşadıkları sıkıntılardan dolayı rahat etmek için (\%24) müracaat edenler, üçüncü sırada ekonomik nedenler (\%10), dördüncü sırada ise ailevi sorunlar $(\% 5)$ ve kalacak yeri olmayanların (\%5) yer aldığ 1 görülmektedir. Bunu beşinci sırada çocukları istemediği için (\%4), ve son sirada gelinleri istemediği için (\%3) müracaat edenler takip etmektedir. 


\section{TARTISSMA VE SONUC}

Bat1 Avrupa ve ABD'de 1970'lerde başlayan yaşlı istismarı ve ihmali konusundaki bilimsel araştırmaların ve koruyucu tedbirlerin, ülkemiz açısından henüz başlangıç aşamasında olduğu nitelendirilebilir. Diğer taraftan yaşlı istismarı alanındaki araştırma zorlukları dikkate alındığında tüm dünyada olduğu gibi ülkemizde de bu alandaki araştırmaların sınırlı düzeyde olduğu söylenebilir. Özellikle batı toplumlarında 21. yüzyılın ilk on yılında yapılan yaşlı istismarı araștırmalarına göre, istismara maruz kalanların genel nüfus içinde $\% 1,4$ ile $\% 10$ oranları arasında değiştiği ifade edilmektedir. ${ }^{12-17-18}$ Ayrıca dünyanın değişik ülkelerinde yapılmış araştırma sonuçlarına göre; yaşlı istismarı ve ihmali Japonya'dan, Güney Kore'ye, İsrail'den, İngiltere'ye, Amerika Birleşik Devletlerine, Kanada'ya, Çin'e ve Hindistan'a kadar çocuk ve kadın istismarı gibi bütün dünya ülkelerini yakından ilgilendiren bir sosyal sorun alanına işaret etmektedir. ${ }^{12}$ 19-30.

Türkiye'de, yaşlı istismarı alanında ilk bilimsel çalışma 1996 y1lında İstanbul ilinde huzurevine girmek için müracaat eden 113 yaşlı ve yaşlı yakınları ile yapılan "Aile İçi Fiziksel Yaşlı İstismarı" konulu araştırmadır. $\mathrm{Bu}$ araştırma sonuçlarına göre; huzurevine girmek için müracaat eden yaşlıların \%60'1 fiziksel istismar dış1 istismara maruz kalırken, \%26'sının fiziksel istismara maruz kaldığ 1 ve yaşlı yakınlarından \%87'sinin yaşlılardan rahatsızlık duydukları belirlenmiștir. Ayrıca fiziksel istismarda bulunanların kimler olduğuna baktığımızda, ilk sırada gelinlerin geldiği, bunu erkek çocukların, damatların, kardeş, kız çocukları ve son sırada torunların takip ettiği görülmüștür. ${ }^{16}$

1999 yılında 120 yaşlı üzerinde yapılan benzer bir çalışmada, yaşlıların \%46'sının psikolojik istismara, \%17,5'inin fiziksel istismara, üç yaşlının ise cinsel istismara maruz kaldığı bulunmuştur. ${ }^{31}$ Ayrıca 2004 yılında İzmir ili İnönü Sağlık Ocağı bölgesinde 65 yaş ve üzerindeki 204 yaşlı ile yapılan bir araştırmada; yaşlıların \%2'sinin fiziksel, \%3'ünün ekonomik istismara maruz kaldığ $1, \% 4$ 'ünün de kesin ihmal bulgusu ve \%29'unda da ihmal bulgusu olduğu saptanmıstır ${ }^{32}$ Yine 2005 yılında Ankara ili Yenimahalle ilçesi Anadolu mahallesinde aile içi yaşlı istismarı sıklığını ve buna etki eden etmenleri saptamak amaciyla 65 yaş üzeri 275 kişi üzerinde araştırma yapılmıştır. Bu araştırma sonuçlarına göre; yaşl1ların \%18'inde aile içi yaşlı istismarı saptanmıştır. Yaşlı istismarının \%41'ini duygusal, \%30'unu ihmal, \%20'sini ekonomik ve \%10'unu fiziksel istismar oluşturmaktadır. ${ }^{33}$ Ayrıca 2005-2009 yılları arasında gerçekleştirilen 1. Türkiye Gerontoloji Araştırması'na göre 7,3 milyon yaşlıdan yaklaşık 200.000 yaşlının istismar ve ihmale maruz kaldığ 1 öngörülmektedir. ${ }^{34}$

Yine 2013 y1lında huzurevinde kalmakta olan 93 yaşlı üzerinde yapılan diğer bir araştırmada, yaşlılardan aile içinde herhangi bir șekilde ihmal ya da istismara maruz kalanların $\% 62$ ile yukarıda ifade edilen Türkiye'deki (1996) ilk çalışma ile benzer sonuçlar içerdiği bulunmuştur. Yaşlılara yönelik istismarda bulunanların kim ya da kimlerden oluştuğuna baktığımızda ilk sırada erkek çocukların (\%25) yer aldığı, bunu ikinci sirada gelinlerin (\%22) takip ettiği, üçüncü sırada eşlerin (\%19), dördüncü sırada kız çocuklarının (\%16), beşinci sırada özellikle çocuğu olmayan yaşlilarla ilgilenmekte olan yeğenlerin (\%11), altınc1 sırada damatların (\%5) ve son sirada torunların (\%2) yer aldığı anlaşılmaktadır.

$\mathrm{Bu}$ çalışma kapsamında ise aile içinde ekonomik istismara uğrayanların \%33 ile yukarıda ifade edilen araştırma bulgularını destekler nitelikte olduğu görülmektedir. Diğer taraftan gelişmiş ve gelişmekte olan ülkelerde yapılan çalışmalar göstermektedir ki yaşlı istismarının kaynağını aile oluşturmaktadır. $\mathrm{Bu}$ araştırma sonuçlarına göre de, yaşlıya yönelik ihmal ya da istismarda bulunanların kaynağ 1 ailedir. Ayrıca araștırma sonuçlarındaki istismar oranlarının yüksek çıkmış olmasının temel nedeni araştırma örnekleminin yalnızca huzurevinde kalmakta olan yaşlılardan oluşmasıdır. Diğer taraftan yaşlı istismar ve ihmaline ilișkin sınırlı sayıdaki araștırmaların çoğunlukla istismar türlerinin tamamını (fiziksel, psikolojik, cinsel ve ekonomik) kapsayıcı nitelikte olduğu dikkate alındığında, bu araştırmanın ise ağırlıklı olarak ekonomik istismar içerikli olması nedeniyle bulguları bire bir karşılaştırma olanağı söz konusu olamamıștır.

Ayrıca yaşlı istismarı ve ihmali olgusu sadece aile içinde meydana gelmemektedir. İstismar ve ihmal vakalarına huzurevleri, bakım ve rehabilitasyon merkezleri gibi sosyal hizmet kuruluşlarının yanı sıra sağlık kurumlarında da rastlamak mümkündür. Ancak ülkemizde basına yansıyan bazı olumsuz haberlerin dışında bilimsel olarak yapılmış bir araştırma bulunmamaktadır. ${ }^{35}$ 
Yine, bu alanda araştırma yapmak kimi zorlukları beraberinde getirmektedir. Aile içinde yaşananların yaşlılar ya da yakınları tarafından gizlenmek istenmesi, birisine söylenmesi durumunda daha fazla istismara maruz kalacağ 1 korkusu ya da utanma duygusu, vakaların tespitini ve araştırma verilerinin elde edilmesini güçleştirmektedir. Diğer taraftan, yasal olarak istismar vakalarının bildirilmesine ilişkin bilgi eksikliği, kurumlar arası koordinasyon yetersizliği, sosyal hizmet uzmanı, psikolog, doktor, hemşire, vb. uzman personelin eksikliği istismar ve ihmalin tespitini zorlaştıran nedenler arasında sayılabilir. ${ }^{16}$

\section{KAYNAKLAR}

1. World Health Organization. 2008. [cited 2008 June]. Available from: http://www.who.int/ageing/publications/EL DER_DocAugust08.pdf

2. Etienne G. K, Linda L. D, James A. M, Anthony B. Z, Rafael L. 2002. World Report on Violence and Health, World Health Organization.

3. Baker A. A. Granny Battering. Modern Geriatrices, 1975; 8: 20-24.

4. Burston G. Do Your Elderly Parents Live in Fear of Being Battered? Modern Geriatrics, 1977; 5: 54-55.

5. Decalmer P. (1997). Clinical Presentation and Management. In. Decalmer P, Glendenning F, editors. The Mistreatment of Elderly People. London: Sage Publications Ltd; 1997. p. 42-73.

6. World Health Organization. 2015. [cited 2015 August]. Available From: http://www.who.int/mediacentre/factsheets/ fs $357 /$ en/index.html.

7. Lai W.L, D. Abuse and Neglect Experienced by Aging Chinese in Canada, Journal of Elder Abuse \& Neglect, 2011; 23(4): 326347.

8. Conner T, Prokhorov A, Page C, Fang Y, Xiao Y, Post A. L. Impairment and Abuse of Elderly by Staff in Long-Term Care in Michigan: Evidence from Structural Equation Modeling, Journal of Interpersonal Violence, 2011; 26(1): 21-33.

9. World Health Organization. 2002. [cited 2002 June]. Available from: http://apps.who.int/iris/bitstream/10665/673 71/1/WHO_NMH_VIP_02.1.pdf.

10. Cripps D. Rights Focused Advocacy and Elder Abuse. Australasian Journal on Ageing, 2001; 20(1): 17-22.
11. Livermore P, Bunt R, Biscan K. Elder Abuse among Clients and Carers Referred to the Cen- tral Coast ACAT: A Descriptive Analysis. Australasian Journal on Ageing, 2001; 20(1): 41-7.

12. Biggs S, Manthorpe J, Tinker A, Doyle M, Erens B. Mistreatment of Older People in the United Kingdom: Findings from the First National Prevalence Study. Journal of Elder Abuse \& Neglect, 2009; 21(1): 1-14.

13. Acierno R, Hernandez M, Amstadter A, Resnick H, Steve K, Muzzy W, Kilpatrick D. Prevalence and Correlates of Emotional, Physical, Sexual, and Financial Abuse and Potential Neglect in the United States: The National Elder Mistreatment Study. American Journal of Public Health, 2010; 100(2): 292-7.

14. Hutton D. Older People in Emergencies: Considerations For Action and Policy Development. Geneva: World Health Organization. 2008.

15. United Nations. 2015. [cited 2015 December]. Available From: http://esa.un.org/unpd/wpp/publications/file s/key_findings_wpp_2015.pdf

16. Artan T. Aile İçi Fiziksel Yaşlı İstismarı. [Domestic physical Elder Abuse]. Yayınlanmamış Yüksek Lisans Tezi. İstanbul Üniversitesi Adli Tıp Enstitüsü Sosyal Bilimler Bölümü. [Unpublished Master Thesis].(1996). Istanbul University Department of Social Sciences Institute of Forensic Medicine, Istanbul, 1996.

17. Cooper C, Selwood A, Livingston G. The Prevalence of Elder Abuse and Neglect: A Systematic Review. Age and Aging, 2008; 37: 151-160.

18. Laumann E. O, Leitsch S. A, Waite L. J. Elder Mistreatment in the United States: Prevalence Estimates from a Nationally Representative Study. Journal of Gerontology, 2008; 63: 248-254.

19. Yan E, Chan K. L, Tiwari A. A Systematic Review of Prevalence and Risk Factors for Elder Abuse in Asia. Trauma, Violence, \& Abuse, 2015; 16(2): 199-219

20. Podnieks E. National Survey on Abuse of the Elderly in Canada. Journal of Elder Abuse and Neglect, 1992; 4: 5-58.

21. Canadian Centre for Justice Statistics. 2000. [cited 2000 May]. Available from: http://www.statcan.gc.ca/pub/85-002x/2012001/article/11643-eng.pdf 
22. Daskalopoulos M. D, Borrelli S. E. Definitions of Elder Abuse in an Italian Sample. Journal of Elder Abuse \& Neglect, 2006; 18 (2-3): 67-85.

23. Mouton C. P, Larme A. C, Alford C. L, Talamantes M. A, Mccorkle R. J, Burge S. K. Multiethnic Perspectives on Elder Mistreatment. Journal of Elder Abuse \& Neglect, 2005; 17 (2): 21-44.

24. The National Center on Elder Abuse (NCEA), 2015. [cited 2015 November]. Available from: www.ncea.aoa.gov

25. Daskalopoulos M, Mullin A. S, Donovan E, Suzuki H. English Perceptions of Elder Abuse. Journal of Elder Abuse \& Neglect, 2006; 18 (2-3): 33-50.

26. O'Keeffe M, Hills A, Doyle M, McCreadie C, Constantine R, Tinker A, Manthorpe J, Biggs S, Erens B. UK Study of Abuse and Neglect of Older People Prevalence Survey Report, National Centre for Social Research, King's College London, 2007.

27. Crosby G, Clark A, Hayes R, Jones K, Lievesley N. (2008) The Financial Abuse of Older People A review from the literature carried out by the Centre for Policy on Ageing on behalf of Help the Aged. Help the Aged 2008. [Cited 2015 December]. Available from: http://www.cpa.org.uk/information/reviews /financialabuse240408[1].pdf.

28. Eisikovits Z, Lowenstein A,Winterstein T, Enosh G. Is Elder Abuse and Neglect a Social Phenomenon? Data from the First National Prevalence Survey in Israel. Journal of Elder Abuse \& Neglect, 2009; 21(3): 253-277.

29. Dong X, Simon M. A, Gorbien M. Elder Abuse and Neglect in an Urban Chinese Population. Journal of Elder Abuse \& Neglect, 2007; 19 (3-4): 79-96.

30. Kalavar M. J, Jamuna D, Ejaz. K. F. Elder Abuse in India: Extrapolating From the Experiences of Seniors in India's "Pay And Stay" Homes. Journal of Elder Abuse \& Neglect, 2013; 25(1): 3-18

31. Sözen M.S, İnancı M.A, Arıcan N, Alkan N, Tüzün B, Şahin C. Abuses on Elderly. 4th International Symposium on Advances in Legal Medicine. Germany, 1999; 22- 25.

32. Keskinoğlu P, Giray H, Pıçakçıefe M, Bilgiç N, Uçku R. Yaşlıda Fiziksel, Finansal Örselenme ve İhmal Edilme. [Elderly Physical, Financial Trauma AND
NEGLECT]. Türk Geriatri Dergisi [Turkish Journal of Geriatrics]. 2004; 7 (2): 57-61.

33. İlhan F. Ankara İli Yenimahalle İlçesi Anadolu Mahallesinde Aile İçi Yaşlı İstismarının Saptanmas1 [Detection of Elder Abuse in the Family in Anatolia Ankara Yenimahalle District neighborhood]. Gazi Üniversitesi Tıp Fakültesi Halk Sağlığı Anabilim Dalı [Gazi University Faculty of Medicine Department of Public Health]. Ankara, 2005.

34. Tufan İ. 2011. [cited 2013 January]. Available from: http:// www. sondakikahaberleri.info.tr

35. Akdemir N, Görgülü Ü, Çınar F. İ. Yaşlı İstismarı ve İhmali [Elder Abuse and Neglect]. Sağlik Bilimleri Fakültesi Hemşirelik Dergisi [Journal of Nursing Faculty of Health Sciences]. 2008; 68-75. 